\title{
Characterization of Humic System in Fertilizer Raw
}

\section{Materials}

Ekaterina Filcheva ${ }^{1}$, Rossitza Ilieva ${ }^{2}$, Kosnstantin Chakalov ${ }^{3}$, Todorka Popova ${ }^{3}$, Valentin Savov ${ }^{3}$ and Mariana Hristova $^{1}$

1. Department of Soil Genesis, Geography and Classification, Nikola Poushkarov Institute of Soil Science, Agrotechnology and Plant Protection, Sofia 1080, Bulgaria

2. Department Common Agriculture, University of Forestry, Sofia 1718, Bulgaria

3. Balkan Plant Science Ltd. Co., Sofia 1000, Bulgaria

\begin{abstract}
The aim of the study was to characterize humus system of natural and artificial products. Humus systems from leonardite, lignite biotransformed with Trichoderma sp. (Plantagra), plant materials after pyrolisis (charcoal) and composts are compared. Humus systems are characterized by Kononova-Belchikova's method, and heavy metals content was measured by atomic absorption spectroscopy (AAS). Humic acids from the International Humic Substances Society (IHSS) collection are the standards for humus substances quality of compared products. Data obtained for leonardite indicate that the studied substances from factory, Izmir, Turkey contain humic acids over $94 \%$. Compared to the standard, heavy metals content in these materials demonstrate high amounts. Organic carbon content in the composts is very low compared to the leonardite materials and IHSS collection, where the heavy metals content is lower. Biotransformed lignite is characterized with lower content of organic carbon, but humic acids are with high degree of humification. Results obtained show that the fourth studied humus systems may be used in agriculture on base of the high humic acids content. It is recommended to measure heavy metals content before applying the materials in agriculture.
\end{abstract}

Key words: Compost, humic acid, leonardite, lignite, sewage sludge, Trichoderma harzianum, Trichoderma viride.

\section{Introduction}

Role of humus in soils is diverse. The content and reserves of $\mathrm{N}$, a major nutrient element in the soil system, largely depend on the total content of organic matter. The quantity and characteristics of soil organic matter have a positive influence on many soil properties, primarily on the soil physical properties and the processes of structure formation. Humus substances interact with mineral colloids, and form complexes in nature and structure of organo-mineral compounds and associates as a result of this change the properties of the mineral colloids. An important role of soil organic matter is to bind heavy metals and some organic contaminants in polluted technogenic soils [1-3].

Corresponding author: Ekaterina Filcheva, professor, research fields: soil science - soil organic matter, composts, organic carbon stocks, etc..
The decreasing of soil organic matter is due to the rapid mineralization of the labile components under the limited input of organic materials in soils. Major sources to replenish the loss of organic carbon are after harvest, such as root residues, organic fertilizers, composts, humus materials of different origin, charcoal, etc.. Nowadays, there is a global trend for a gradually replacement of chemical fertilizers by natural products. Humic substances are promising raw material, as they naturally occur in high amounts in Bulgarian lignites [4].

A significant number of studies focus their attention on the role of lignin decomposing enzyme systems, like peroxidase [5, 6]. A new isolate of Trichoderma atroviride has been shown to grow on low rank coal as a sole carbon source; T. atroviride ES11 degrades $82 \%$ of a particular type of coal over a period of $21 \mathrm{~d}$ [7]. In the previous studies, the possibility for 
biotransformation of lignite by Trichoderma has been shown [8]. Some of this material can bio-solubilized by bacteria (such as Bacillus sp. and Pseudomonas sp.) in bioreactors, and they have significant physiological effect on plants [9]. So, the aim of this study was to characterize humic systems of certain natural and commercial products with a view to determine their potential as enhancers of the humus status of soils treated with them, or their ability to stimulate plants.

\section{Materials and Methods}

Different materials were compared for humus system in the study:

(1) Humus substances produced from leonardite in a factory (YEM-MIKS Company/Ant Organic Fertilizer-Humic Acid Manufacturer), Izmir, Turkey were dissolved in distill water ( $1 \mathrm{~g}$ in $250 \mathrm{~mL})$;

(2) Humus substances produced from $1 \mathrm{~g}$ of powdered lignite and biotransformed lignite with Trichoderma sp. prepared by Research Organization and Manufacture of Bioproduct (ROMB), Bulgaria;

(3) Composts contain sewage sludge, zeolite and barks after three months period of aerobic composting;

(4) Plant materials after pyrolisis (charcoal);

(5) The humic acids from International Humic Substances Society (IHSS) collection were used as a referent material (etalon).

The fourth series of humic substances are studied by content and composition of organic carbon by the following method.

Soil organic carbon content was determined by modified Turin's method $[10,11]$. The method is based on dichromate oxidation and digestion at $125{ }^{\circ} \mathrm{C}, 45 \mathrm{~min}$, in presence of $\mathrm{Ag}_{2} \mathrm{SO}_{4}$ and $\mathrm{FeSO}_{4}\left(\mathrm{NH}_{4}\right)_{2} \mathrm{SO}_{4} \cdot 6 \mathrm{H}_{2} \mathrm{O}$ titration, phenyl anthranilic acid as an indicator.

Soil organic matter composition was determined by the method of Kononova-Belchikova [10, 11]. Total humic and fulvic acids (Cextr.) were determined after extraction with mixed solution of $0.1 \mathrm{M} \mathrm{Na}_{4} \mathrm{P}_{2} \mathrm{O}_{7}$ and
0.1 $\mathrm{M} \mathrm{NaOH}$, while "free" and $\mathrm{R}_{2} \mathrm{O}_{3}$ bounded humic and fulvic acids $\left(\mathrm{C}_{\mathrm{NaOH}}\right)$ were determined after extraction with $0.1 \mathrm{M} \mathrm{NaOH}$, with ratio of soil:solution $=1: 20$ for the extractions. Humic and fulvic acids in both extracts - Cextr. and $\mathrm{C}_{\mathrm{NaOH}}$ were separated by acidifying the solution with $0.5 \mathrm{M}$ sulfuric acid. Optical characteristics $\left(\mathrm{E}_{4} / \mathrm{E}_{6}\right)$ show the degree of condensation and aromatization of humic acids, and it was determined at the optical density $\lambda=$ $465 \mathrm{~nm}$ and $665 \mathrm{~nm}$, respectively.

Nutrient elements were determined with conventional methods, $\mathrm{pH}$ was measured with pH-meter [12] and heavy metals were measured by atomic absorption spectroscopy (AAS-Perkin Elmer 4100).

\section{Results and Discussion}

The humus substances produced from leonardite in Izmir, biotransformed lignite in Bulgaria, composts and plant materials after pyrolisis are powdered with dark brown to black color. Their solubility in water is very good and does not require filtration before testing. Apparently before the treatment of plants or soils, the solubility is similar to the standard of IHSS.

Characteristics of humus substances from leonardite are presented in Table 1. It shows that $\mathrm{pH}$ is alkali and strong alkali reaction. Total organic carbon is lower compared to the substances of IHSS collection (etalon). The most similar in content of total organic carbon is humic powder, compared to the standard, but the differences show that they are enriched with humic substances. The high percent of humic acids (over 94\%) was established in the studied materials from Izmir factory, while, in the etalon it is close to $87 \%$. The remaining preparations contain from $7 \%$ to $10 \%$ more humic substances compared with the standard. Optical characteristics $\left(\mathrm{E}_{4} / \mathrm{E}_{6}\right)$ are similar to those of etalon, which is an indicator for average maturity [13]. The total content of nutrients is high, but it is negatively concerning, especially $\mathrm{Na}$ content.

Dried biotransformed lignite prepared by Research 
Table 1 Characteristics of humus substances from leonardite.

\begin{tabular}{llllllll}
\hline Humus substances & $\mathrm{pH}$ & $\mathrm{C}(\%)$ & $\begin{array}{l}\text { Humic acids (\%) in the } \\
\text { substances }\end{array}$ & $\mathrm{E}_{4} / \mathrm{E}_{6}$ & $\mathrm{P}(\%)$ & $\mathrm{K}(\%)$ & $\mathrm{Na}(\%)$ \\
\hline Combi 2 & 7.95 & 24.69 & 100.00 & 6.11 & 0.047 & 20.24 & 15.31 \\
Copper-zinc humate & 8.30 & 24.95 & 93.82 & 5.81 & 0.071 & 19.26 & 6.15 \\
Houmphos dry & 8.80 & 21.73 & 96.38 & 5.88 & 3.471 & 33.0 & 2.15 \\
Humix powder & 8.50 & 27.88 & 100.00 & 6.08 & 0.072 & 20.12 & 2.31 \\
Fer humate & 7.50 & 25.49 & 94.90 & 6.23 & 0.080 & 18.40 & 23.37 \\
\hline Etalon from IHSS & 7.60 & 29.9 & 86.58 & 5.89 & & & \\
\hline
\end{tabular}

Table 2 Characteristics of humus substances in biotransformed lignite.

\begin{tabular}{lllccc}
\hline \multirow{2}{*}{$\begin{array}{l}\text { Biotransformation with } \\
\text { strains }\end{array}$} & $\begin{array}{l}\text { Total organic } \\
\text { carbon (\%) }\end{array}$ & $\begin{array}{c}\text { C in pyrophosphate } \\
\text { extract }\end{array}$ & Humic acid & Fulvic acids & \multirow{2}{*}{$\mathrm{E}_{4}: \mathrm{E}_{6}$} \\
\cline { 3 - 6 } & 33.99 & $19.72^{\mathrm{a}}(58.02)^{\mathrm{b}}$ & $15.76(46.45)$ & $3.96(11.65)$ & 7.16 \\
\hline T. viride St-4 & 33.35 & $19.72(59.13)$ & $13.94(41.80)$ & $5.78(17.33)$ & 7.23 \\
T. viride AU & 34.00 & $20.61(60.62)$ & $12.63(37.15)$ & $7.98(23.47)$ & 7.15 \\
T. harzianum St-118 & 34.23 & $21.12(61.70)$ & $13.40(39.15)$ & $7.72(22.55)$ & 7.09 \\
T. viride BB-100 & 33.69 & $20.00(59.36)$ & $14.75(43.78)$ & $5.25(15.58)$ & 7.64 \\
T. harzianum ABT & & & & &
\end{tabular}

a: $\%$ of sample mass; b: $\%$ of the total carbon.

Table 3 Characteristics of nutrient elements, dry mass and heavy metals in Plantagra (mg/L).

\begin{tabular}{ll}
\hline Index & Plantagra (T. harzianum + P. chlororaphis + P. putida $)$ \\
\hline Dry matter & 15,100 \\
Total organic carbon & 5,341 \\
Total N & 456.26 \\
$\mathrm{P}_{2} \mathrm{O}_{5}$ & 164.00 \\
$\mathrm{~K}_{2} \mathrm{O}$ & 4,150 \\
$\mathrm{NaO}$ & 285.00 \\
$\mathrm{CaO}$ & 281.61 \\
$\mathrm{MgO}$ & 50.00 \\
$\mathrm{Fe}$ & 20.00 \\
$\mathrm{Mn}$ & 0.27 \\
$\mathrm{Cu}$ & 0.24 \\
$\mathrm{Zn}$ & 5.47 \\
\hline
\end{tabular}

Organization and Manufacture of Bioproduct (ROMB) was brown globular powders with gray green hue. Variants 1 (T. viride St-4) and 2 (T. viride $\mathrm{AU}$ ) are with a slight greenish tint, while 3 (T. harzianum St-118), 4 (T. viride BB-100) and 5 (T. harzianum ABT) are barely noticeable gray and very strong greenish hue. This is due to the formation type of microflora. The preparations are virtually insoluble in water.

Data presented in Table 2 show there is no substantial difference in biotransformation with $T$. viride St-4 and T. harzianum ABT, but there is substantial difference of difference strains of biotransformation of organic substances to fulvic acids. The advanced stage of humusformation in biotransformed lignite with strains $T$. viride $\mathrm{St}-4$ formed 46\% humic acid and less fulvis acids $11.65 \%$ of the total carbon, and St-118 formed $37.15 \%$ humic acid and the maximum fulvic acids $23.47 \%$. It is similar for T. viride BB-100, where contains $22.55 \%$ fulvic acids of the total carbon. Referent strains $T$. viride $\mathrm{AU}$ and T. harzianum $\mathrm{ABT}$ contain humus substances with low condensation and aromatization, probably because process of biodegradation prevails 
and this short inoculation process is not sufficient to form more mature humic acids.

Humus substances in coal are in a high stage of maturity. Method of impact with micro-fungi allows to break chains, where low molecular compounds with a higher physiological activity are formed [14]. The chelated forms of $\mathrm{Cu}$ and $\mathrm{Zn}$ promote the biodegradation of lignite, increasing the fulvic acids, while $\mathrm{Ca}$ and $\mathrm{Mg}$ increase the content of humic acid up to $97 \%-99.8 \%[8,15]$.

Plantagra is a product developed on the bases of alkali hydrolysis of biotransformed lignite from Stanyansi with strains T. harzianum and T. viride. It is with dark brown color and balanced natural content of biogenic elements. It is intended to treat plants and peat mixture in combination of hydroponic solution.

Data in Table 3 show that the developed product demonstrate a qualified amendment due to the high organic carbon content, nutrient elements and very low heavy metals content.

Field experiments on maize hybrids $\mathrm{Kn} 435, \mathrm{Kn}$ 509 and Kn M625 with humic substances took place in the Maize Research Institute in Knezha in 2008-2009. The organic fertilizer was administered by foliar feeding in the 8-10 leaf phase. The rate of introduction was $50 \mathrm{~mL} / \mathrm{ha}$ for each iteration. Two additional fertilizer rates were tested on $\mathrm{Kn} 435$ with
$800 \mathrm{~mL} / \mathrm{ha}$ and $1,200 \mathrm{~mL} / \mathrm{ha}$. The results show that treating with $1,200 \mathrm{~mL} / \mathrm{ha}$ Plantagra increases yield with $12.27 \%$. Especially clear is the trend of increasing protein content in the range of $2.27 \%$ to $18.62 \%$ on the tested hybrids [16]. Treatment of poinsettia with humic substances from biotransformed lignite (Plantagra) improved $\mathrm{N}$ nutrition with urea. The ornamental quality of the culture became better [17].

Biodegradable lignite with Trichoderma sp. further biodegraded in bioreactor with bacteria Bacilus sp. and Pseudomonas sp. allows to obtaining liquid bio-humates with very good water solubility. They are dark brown, subject to filtration for separate minerals and form microflora. They are liquid or dried in powder dryer, and have a slight smell of ammonia. Nutrients are well balanced and they also have an incentive effect, so they are good bio-fertilizer. They contain, according to the manufacturer, live microorganisms, which further increase the impact of their application.

As shown in Table 4, dry material of biotransformed soluble humic substances is $33.11 \%$ of the total organic carbon, while the standard is $29.99 \%$. In this biotransformation and alkaline hydrolysis, the percentages of extractable fulvic acids increase and their relative content to the total carbon increases from $10.94 \%$ in biotransformation lignite to almost twice

Table 4 Characteristics of biotransformed lignite and Plantagra.

\begin{tabular}{lll}
\hline Index & Biotransformed lignite & Plantagra dryed in pulverize dryer \\
\hline Dry mass (\%) & 59.55 & 91.90 \\
Total organic carbon $(\%)$ & 43.13 & 33.11 \\
$\mathrm{C}(\%)$ in $\mathrm{NaOH}$ and $\mathrm{Na}_{4} \mathrm{P}_{2} \mathrm{O}_{7}$ & $24.59^{\mathrm{a}}(57.01)^{\mathrm{b}}$ & $26.42^{\mathrm{a}}(79.79)^{\mathrm{b}}$ \\
$\mathrm{Humic}$ acid (\%) & $19.87(46.07)$ & $20.01(60.43)$ \\
Fulvic acids (\%) & $4.72(10.94)$ & $6.41(19.35)$ \\
$\mathrm{N}(\%)$ & 1.46 & 1.22 \\
$\mathrm{P}_{2} \mathrm{O}_{5}(\%)$ & 0.086 & 1.46 \\
$\mathrm{~K}_{2} \mathrm{O}(\%)$ & 0.44 & 18.03 \\
$\mathrm{Na}_{2} \mathrm{O}(\%)$ & 0.20 & 0.54 \\
$\mathrm{CaO}(\%)$ & 5.82 & 4.58 \\
$\left.\mathrm{MgO}^{\circ} \%\right)$ & 0.78 & 0.56 \\
$\mathrm{Fe}_{2} \mathrm{O}_{3}(\%)$ & 1.42 & 1.01 \\
$\mathrm{Al}_{2} \mathrm{O}_{3}(\%)$ & 2.24 & 1.43 \\
$\mathrm{~S}(\%)$ & 1.82 & 1.43 \\
\hline
\end{tabular}

a: \% of soil mass; b: \% of the total carbon. 
Table 5 Characteristics of charcoal.

\begin{tabular}{|c|c|c|c|c|c|c|c|}
\hline Substances & & $\mathrm{pH}$ & $\mathrm{C}(\%)$ & $\mathrm{P}(\%)$ & $\mathrm{K}(\%)$ & $\mathrm{Na}(\%)$ & $\mathrm{Cu}(\mathrm{mg} / \mathrm{kg})$ \\
\hline Plants after pyrolisis & & 6.50 & 30.44 & 0.05 & 0.25 & 20.00 & 20.00 \\
\hline Treatments & $\mathrm{pH}$ & $\mathrm{C}(\%)$ & $\begin{array}{l}\text { Humic ac } \\
\text { carbon of }\end{array}$ & $\begin{array}{l}\text { of the total } \\
\text { osts }\end{array}$ & $\mathrm{E}_{4} / \mathrm{E}_{6}$ & $\mathrm{~K}(\%)$ & $\mathrm{Na}(\%)$ \\
\hline Sewage sludge (SS) & 6.80 & 16.08 & 7.77 & & 8.15 & 0.043 & 0.011 \\
\hline SS + zeolite $(Z)$ & 6.80 & 13.68 & 8.19 & & 7.55 & 0.371 & 0.050 \\
\hline SS + barks (B) & 6.80 & 13.56 & 7.74 & & 10.43 & 0.061 & 0.010 \\
\hline $\mathrm{SS}+\mathrm{Z}+\mathrm{B}$ & 6.80 & 12.12 & 9.24 & & 7.22 & 0.197 & 0.029 \\
\hline $\mathrm{SS}+\operatorname{modified} \mathrm{Z}+\mathrm{B}$ & 6.50 & 13.86 & 7.28 & & 12.90 & 0.480 & 0.061 \\
\hline
\end{tabular}

The modified zeolite according to Ref. [18].

Table 7 Heavy metals content in humus substances ( $\mathrm{mg} / \mathrm{kg})$.

\begin{tabular}{llll}
\hline Materials & $\mathrm{Cu}$ & $\mathrm{Zn}$ & $\mathrm{Pb}$ \\
\hline Combi 2 & 9,575 & 14,375 & 153.0 \\
Copper-zinc humate & 10,600 & 9,375 & 143.0 \\
Houmphos dry & 35.00 & 775 & 95.0 \\
Humix poweder & 37.50 & 95.0 & 20.0 \\
Fer humate & 75.00 & 323.0 & 100.0 \\
Biotransformed lignite & 29.80 & 53.00 & \\
Plantagra & 37.40 & 66.50 & \\
Sewage sludge (SS) & 491.00 & 2,285 & 64 \\
\hline
\end{tabular}

$(19.35 \%)$ in Plantagra dryed in pulverize dryer.

Compared the characteristics of biotransformed lignite and Plantagra, it was established that pyrophosphate-extracted organic carbon and humic acids prevail in the Plantagra product (Table 4). Nutrient elements content are similar for both products.

Charcoal is a plant biomass derived materials, produced from pyrolisis with black color. The main benefits occur with additions of biochar, such as enhance plant growth, suppress gas emissions, store carbon in a long term stable sink, reduce soil acidity, improve soil water handling characteristics and increase soil levels of available nutrients. Product, obtained by pyrolisis, easily crush to fine black dust, demonstrates good characteristics with favorable $\mathrm{pH}$, high percent carbon content and nutrient elements (Table 5).

Composting is a proper way to maintain and increase soil fertility. Five compost obtained after composting of different materials were listed in
Table 6. Sludge (SS) from wastewater treatment plant, Sofia, Bulgaria, is rich in organic matter and nutrients, Zeolite $(\mathrm{Z})$ is from the Rhodopes mountain, Bulgaria and barks (B) are from conifers. These materials are mixed in various proportions and were aerobically composted for three months [18]. Best results for humic acids content and optical characteristics (maturity degree of humic acids) were in the treatment of $\mathrm{SS}+\mathrm{Z}+\mathrm{B}$. Neutral $\mathrm{pH}$ is very favorable for plant growth, but the content of total organic carbon and humic acids are lower than standard (etalon) and humic substances from Izmir, Turkey. Optical characteristics showed a low level of maturity. Humic acids in composts are bound to alkali-earth ions, which has a positive effect on both the soil and water physical properties and reduce the risk of washing of mobile organic substances down the profile depth.

These variants were studied where pot experiments with polluted and unpolluted soils were carried out. The results obtained manifested improvement of soil fertility compared to the control variants [18]. The 
maximum humic acids and lower ratio $\mathrm{E}_{4} / \mathrm{E}_{6}$ (more condensed humic acids) are formed in the treatment $\mathrm{SS}+\mathrm{Z}+\mathrm{B}$. This one could be recommended as the best variants as a soil amendment.

The content of heavy metals in biotransformed lignite and Plantagra is low (Table 7). Some of the substances of Izmir factory contain high amounts of $\mathrm{Cu}$ and $\mathrm{Zn}$, which is related to their use in agriculture in certain circumstances. SS contains high amounts of $\mathrm{Cu}$ and $\mathrm{Zn}$, due to the including of industrial waters in purification of waters. In the presence of zeolite and barks, after a period of composting, respectively, maturation of compost and doses of application allowed their use as a soil amendment.

\section{Conclusions}

To be mentioned, application of different substances for soils and plants treatment will increasingly become nowadays more applicable in agriculture. Characteristics of the products presented in this paper provide valuable information on the content and composition of organic matter, maturity of humic substances and content of heavy metals. This information is of great importance in the application of humic preparations (the amount and level of their application). It is necessary for manufacturers, businessman, consultants and users in relation to the production, dissemination and application of humic substances. Depending on the objectives, the farmer may choose a different product derived from leonardite, lignite, charcoal or composts.

Studied soluble humic preparations are similar or superior to standard in their quality. This indicates that manufacturers strive to achieve a standard quality of humic preparations. Biosolubilizated preparations are intended for the stimulation of plants, because they contain more fulvic acids.

Biotransformed lignites with different Trihoderma strains have more variable ratio between humic acids and fulvic acids, which means that they are intended for treatment of various types of soils.
Application of amendments in sludge composting accelerates composting process and improves the quality of compost. Combining barks and zeolites as additives is better than submitting zeolites only.

It is recommended for application of charcoal to different additives, as sewage sludge, composts, etc., as amendments to soils.

\section{References}

[1] Filcheva, E. 2004. "Comparative Characteristics of Soils in Bulgaria in Content, Composition and Stocks of Organic Matter." Habilitation thesis, NCAS, Institute of Soil Science "Nikola Poushkarov", Sofia.

[2] Filcheva, E. 2007. Characteristic of Bulgarian Soils with Content, Composition and Stocks of Organic Matter: Grouping of Bulgarian Sols-Sustainable Land Management. Sofia: Advertising and Publishing House, Minerva, 191. (in Bulgarian)

[3] Flicheva, E. 2015. Characteristics of Soil Organic Matter of Bulgarian Soils. Verlag: Lap Lambert Academic Publishing, 177.

[4] Stefanova, M., Velinova, D., Marinov, S. P., and Nikolova, R. 1993. "The Composition of Lignite Humic Acids." Fuel 72 (5): 681-4.

[5] Fakoussa, R. M. 1994. "The Influence of Different Chelators on the Solubilization/Liquefaction of Different Pretreated and Natural Lignites." Fuel Process Technol. 40 (2-3): 183-92.

[6] Fakoussa, R. M., and Hofrichter, M. 1999. "Minireview: Microbiology and Biotechnology of Coal Degradation." Appl. Microbiol. Biotechnol. 52 (1): 25-40.

[7] Silva-Stenico, M. E., Vengadajellum, C. J., Janjua, H. A., Harrison, S. T. L., Burton, S. G., and Cowan, D. A. 2007. "Degradation of Low Rank Coal by Trichoderma atroviride ES11.” J. Indus. Microbiol. Biotechnol. 34 (9): 625-31.

[8] Angelova, G., Chakalov, K., Popova, T., and Savov, V. 2009. "Influence of $\mathrm{Cu}, \mathrm{Mn}$ and $\mathrm{Zn}$ Concentration on the Biotransformation of Humic Substances of Lignite." Biotechnology and Biotechnological Equipment 23: 796-800.

[9] Chakalov, K., Savov, V., Metodieva, C., Again, N., Angelova, G., and Popova, T. 2016. "Bio-solubilized Humic Substances from Turkey and Russia as Stimulators or Antistress Agents in Hydroponics." Present at the 3rd National Humic Substances Congress with International Participation, November 3-5, 2016, Konya, Turkey.

[10] Kononova, M. 1966. Soil Organic Matter, 2nd ed.. Oxford, England: Pergamon Press, Inc., 544. 
[11] Filcheva, E., and Tsadilas, C. 2002. "Influence of Cliniptilolite and Compost on Soil Properties." Commun. Soil Sci. Plant Analysis 33 (3-4): 595-607.

[12] Page, A. L., Millerand, R. H., and Keeney, D. R., eds. 1982. Methods of Soil Analyses. Chemical and Microbiological Properties, 2nd ed.. Madison, WI: American Society of Agronomy, Inc., Soil Science Society of America. Inc..

[13] Artinova, N. 2012. "Humus Status of Different Types in Bulgaria.” Soil Sci. Agrochem. Ecol. 4: 11-53.

[14] Chakalov, K., Popova, T., Savov, V., and Angelova, G. 2012. "Study of Some Physiological Effects of Humic Substances Extracted from Lignite Biotransformed by Trichoderma harzianum." J. of Arts and Science 14 (1): 709-17.

[15] Angelova, G., Chakalov, K., Popova, T., and Savov, V. 2012. "Modeling of Solid-State Cultivation of Trichoderma in Order to Obtain Natural Substances with High Cation-Exchange Capacity.” New Biotechnology 29: 205.
[16] Savov, V., Valchinkova, P., Bratkova, S., Angelova, G., Popova, T., and Chakalov, K. 2009. "Effect of Microbial, Enzyme and Humic Substances on Mineral Nutrition and Grain Quality of Maize Hybrids Kn 509 and Kn M 625.” Biotechnology and Biotechnological Equipment 23 (2): 905-8.

[17] Chakalov, K., Popova, T., Savov, V., and Angelova, G. 2008. "Influence of Humics Containing Materials on Poinsettia Hydroponics." In From Molecular Understanding to Innovative Application of Humic Substances, edited by Perminova, I. T., and Kulikova, N. A. Vol. 2. Moscow, Russia: International Humic Substances Society, 627-30.

[18] Tsadilas, C., Rousseva, S., Filcheva, E., Bojinova, P., Samaras, V., Chakalov, K., Petkova, G., Stanislavova, L., Christov, I., Marinova, S., Valev, V., Krasteva, V., Popova, T., and Setatou, H. 2000. "Greek-Bulgarian Research Project in Agroecology: Agricultural Use of Sewage Sludge and Its Impact on Physical and Chemical Properties of Soil.” J. Balkan Ecology 3 (2): 9-48. 